\title{
Exploring the Research Mindset and Information-Seeking Behaviors of Undergraduate Music Students
}

\author{
Joe C. Clark and Jennifer Johnstone
}

\begin{abstract}
This article examines the mindset and process of undergraduate music majors conducting research in their discipline. While working with students in a writing-intensive music history class, the authors conducted several surveys, focus groups, and task-based assessments. Results indicated that most were overconfident in their research abilities, lacked experience with the research process, and struggled to locate and properly cite scholarly sources. Based on existing literature, music students exhibited research practices similar to those in other academic fields.
\end{abstract}

\section{Introduction}

Classroom instructors and librarians are frequently unaware of incoming students' backgrounds, past research experiences, and writing proficiencies. Librarians incorporate information literacy skills into their instruction and interactions with students, while faculty focus on content. Like many disciplines, academic skills for undergraduate music students are often overshadowed by an emphasis on applied (that is to say, performance) skills. Music curricula generally require a number of low-credit courses (in other words, ensembles, conducting, private lessons, piano class) resulting in a considerable time commitment of preparation and practice. Additionally, these students have a number of resource types for music study, including video, audio, reference materials for context and background, scores, books, and articles. The myriad of webbased and informal sources of information available to students leads to additional questions about music students' research processes, beliefs, preferences, and abilities.

Although the focus of this research is on music undergraduates, some of the findings may apply to university students in a number of other disciplines. The authors devised this study in an attempt to answer the following questions: What types of research have undergraduate music majors conducted? How comfortable are they with various aspects of research? How important are research and writing skills to these students? What steps do they take in their research and writing? How frequently do they seek assistance, and to whom do they turn for help? And finally, how well do students find, use, and cite quality resources?

*Joe C. Clark is Associate Professor and Head of the Performing Arts Library, and Jennifer Johnstone is Assistant Professor in Musicology/Ethnomusicology, both at Kent State University; e-mail:jclark88@kent. edu, jljohns5@kent.edu. (C2018 Joe C. Clark and Jennifer Johnstone, Attribution-NonCommercial (http:// creativecommons.org/licenses/by-nc/4.0/) CC BY-NC. 


\section{Background}

The study was conducted at the Kent campus of Kent State University, a public research institution in northeast Ohio comprising eight campuses. The Kent campus has an enrollment of 28,981 students, 125 of whom are undergraduate music majors in the School of Music. The Performing Arts Library opened in 2010 and is located in the same building as the School of Music. Working with teaching faculty, its librarians provide instruction sessions for the music, theatre, and dance courses.

Undergraduate music degrees at the Kent campus include a Bachelor of Arts in music and a Bachelor of Music in composition, performance, or music education. Regardless of their chosen area of concentration, all music majors take a Music History II course, which covers Western Art Music from 1750 to 1945. ${ }^{1}$ The strong focus on research and writing in this course provided an ideal vehicle for our study. Course requirements include essay-based homework assignments and exams as well as one conference-length research paper (approximately 2,000 words) comprising an outline, bibliography, a rough draft, and a final draft.

\section{Literature Review}

While no published mixed-method studies specifically address the research process of music students, a number have explored how university students conduct research. Head's 2007 investigation examined the research process of upper-division humanities and social science students, which paralleled many of the areas investigated in the present study. ${ }^{2}$ She found that students' most frequent first step was to consult their course textbook or class readings. Research obstacles included procrastination, not understanding the specifics and expectations for assignments, and difficulties with finding and evaluating resources.

D'Couto and Rosenhan's work suggested that students want instant access, are self-reliant and reluctant to seek out librarians, and that time constraints influence their research process. ${ }^{3}$ The transition from Google to library resources was difficult for many, and, while Google did not provide the same level of credibility, students used it to begin their research. D'Couto and Rosenhan's study also discovered that library instruction increased students' awareness of library resources. When requiring help, students were more likely to go to their instructors than to seek out librarians.

Head (2013) found that most incoming freshmen, overwhelmed by the number of print and electronic resources available in their academic libraries, were unsure how to use or access them. ${ }^{4}$ Dubicki used student essays describing their research process and discovered that undergraduates encountered significant initial anxiety. ${ }^{5}$ Students acknowledged that research is an iterative process, and Dubicki noted that scholarly articles made up 53 percent of sources cited in the 76 analyzed research papers. Mizrachi observed that more than half of the undergraduates interviewed began their research on a public website or search engine. ${ }^{6}$ She also noted that almost half of her study participants could not articulate a systematic approach for establishing website credibility. According to Colón-Aguirre and Fleming-May, students recognized the authority of library resources over freely available websites, but most generally used search engines and, subsequently, free websites unless instructed otherwise. ${ }^{7}$

Asher and Duke studied the information-seeking and evaluative skills of undergraduates at Illinois Wesleyan University, and were

...surprised at the extent to which students appeared to lack even some of the most basic information literacy skills that we assumed they would have mastered in high school; understanding how information is organized, evaluating sources appropriately, and how best to access library-owned sources (books included). 
Moreover, and perhaps most frustrating for librarians, students showed an almost complete lack of interest in seeking assistance from librarians during the search process. ${ }^{8}$

Research by Miller and Murillo confirmed previous studies' findings that students prefer receiving research help from friends or their professors over librarians. ${ }^{9}$

Nonlibrary resources appear to play a significant role in students' research behaviors. Todorinova reported that those who used Wikipedia were likely to revisit it or search for additional information through Google rather than library resources; however, they generally did not use Wikipedia's reference section. ${ }^{10}$ She also found that students claimed ease of access as the primary consideration when choosing resources. Bloom and Deyrup concluded that "Google has had the largest influence on undergraduate research habits, so much so that it is the major impediment for them to understand library information structures and engaging with the scholarly literature in a meaningful way."11 The study also suggested that students were overconfident in their online research skills.

Other studies confirm that student confidence levels do not always correspond to their actual abilities. Gross and Latham found that those who lacked proficient information literacy possessed an inflated view of their skills, while students who ranked at a proficient level enjoyed a more realistic understanding of their abilities. ${ }^{12}$ Molteni and Chan also learned, in surveying undergraduate health profession students, "that confidence does not appear to be a reliable indicator of competence."13

Several inquiries have explored the information-seeking behavior of faculty, professionals, students, archivists, and librarians in fields allied to music. Medaille's study on practicing theatre artists revealed that information seeking and gathering was critical to their creative process. ${ }^{14}$ Robinson's examination of dance faculty's research behaviors found that peers were their most valued resource. ${ }^{15}$ Marini's survey of theatre scholars, librarians, and archivists confirms that librarians and archivists need to do more to integrate into the communities that they serve. ${ }^{16}$

Previous research suggests that music students use both library and nonlibrary resources in the course of their studies. In examining the needs of performing arts students, Mayer found that participants in her music focus group generally began their research on the Internet and used the library and its resources later in the process. ${ }^{17}$ Clark found that all surveyed students in an online Master's of Music in Music Education program had accessed library resources (100\% used the institution's journal databases and full text, while $72 \%$ used the library's online reference databases), and that usage of Google and YouTube was 90 percent and 79 percent respectively. ${ }^{18}$ Dougan observed that music students who used Google as a reference source were often directed to Wikipedia and other free websites. ${ }^{19}$ According to Clark's 2013 study, important factors in resource selection include ease of access, immediate gratification, and the ability to find the exact item. ${ }^{20}$ Dougan also noticed a difference in the information-seeking behaviors of underclass, upperclass, and graduate students, as well as among music students in different areas of study (that is, musicology, performance, theory, music education). ${ }^{21}$ She theorized that underclass students typically conduct queries based on faculty recommendations and that the nature of their assignments differ from those of upperclass and graduate students. She also found that musicologists and performers tended to use the library's audio subscription databases at a high level. Performers searched for scores more than other groups.

\section{Methodology and Data Analysis}

The primary participant pool for this Spring 2016 study, which received approval 
from the Institutional Review Board, was School of Music juniors and seniors. Most came from the Music History II course, which had an enrollment of 33. The authors supplemented the Research Task Assessment and focus groups with other upperclass music students to ensure adequate participant numbers. To avoid coercion and ensure anonymity, the investigator who was not teaching the Music History course administered the surveys and focus groups.

The researchers gathered data through several means, including two paper surveys administered during the Music History II class, two focus groups, a Research Task Assessment (described below), and an analysis of sources and citation abilities from students' final term papers. Survey 1 gauged student perceptions of and experience with the research process at the beginning of the semester. Survey 2 , which was administered at the end of the semester, measured their reported research practices and experiences.

The focus groups delved into the themes raised in the surveys, allowing for qualitative data collection on students' perceptions and processes (questions in appendix A). Near the end of the semester, twelve students participated in the Research Task Assessment (RTA) sessions, which required students to find, use, and cite resources, and included pre- and post-assessment questionnaires and follow-up verbal reports (see appendix B).

The authors coded quantitative results into version 22 of IBM's SPSS Statistical software and entered open-ended responses into a Word document. They also used the website http://langtest.jp for some means and standard deviation calculations, and Excel's correlation function. The authors recorded and transcribed the two focus groups in Word documents.

\section{Demographics}

All but one of the music majors in this study were upperclassmen (in other words, juniors or seniors). Most (80\%) were between the ages of 18 and 25. The average participant grade point average was 3.3. There was an equal division of male and female students in the surveys and Research Task Assessments; however, the majority of focus group participants were female $(71 \%)$.

While music concentrations varied among study participants, music education was the most common. Fifty-seven percent of survey 1's respondents and 61 percent of survey 2's respondents were music education majors. Performance majors comprised 17 percent (survey 1) and 21 percent (survey 2) of respondents. The other three majors-composition, BA program in music, and a joint degree of music education and performance-were much less common. Far fewer music education students participated in the focus groups; they accounted for only 43 percent.

\section{Student-Reported Data}

\section{Past Research Experiences and Importance of Research Skills}

When asked about previous research activities in survey 1, participants indicated that they had written more papers for their nonmusic courses. Ninety-seven percent reported having produced at least one 3-page paper for a nonmusic class, compared to 75 percent for music courses. Sixty-four percent of students had produced at least one short paper (1-2 pages in length) outside of music, compared to 36 percent for music classes. Figure 1 illustrates students' past experiences with research-related activities for music courses.

The initial survey also had students rate the importance of the following skills for music majors: music composition, performing, teaching, research, improvisation, and writing. The rank-order scale assigned 1 as the most important skill for a music major, and 6 as least important. Performing skills ranked first, with teaching skills close behind $(M=1.78, S D=.974$ and $M=1.85, S D=1.064$ respectively). The remaining four were 


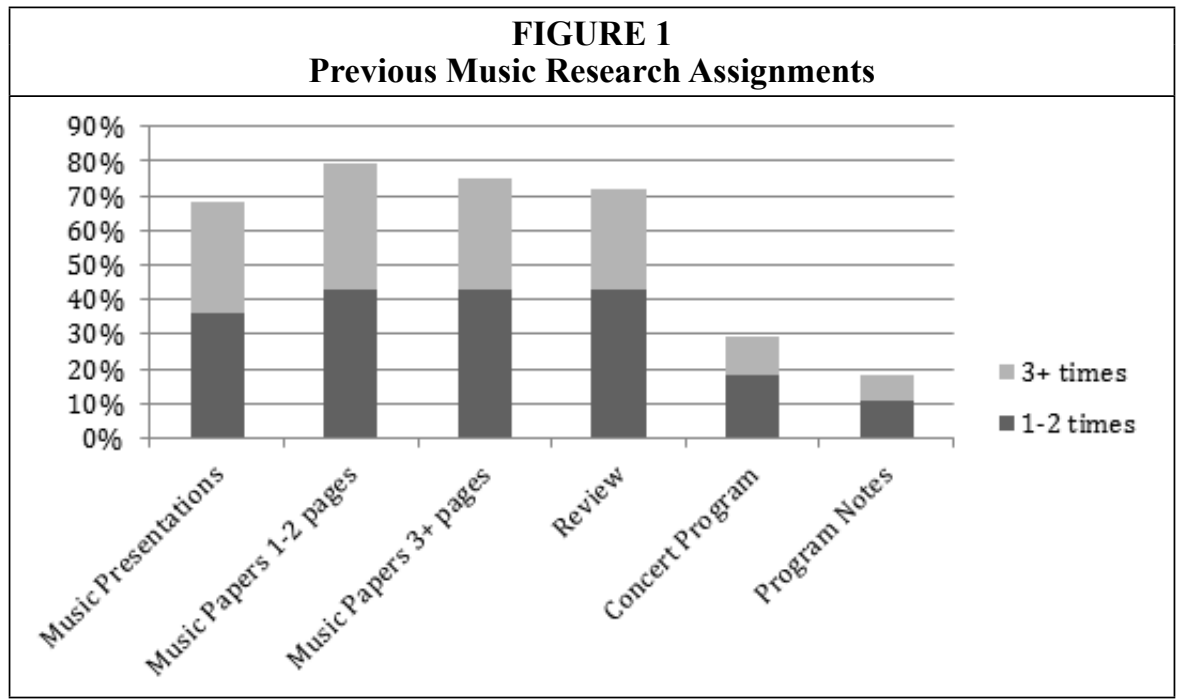

clustered together between means of 3.93 and 4.41. Research and writing skills were third and fourth in importance, with $M=3.93, S D=1.492$ and $M=4.30, S D=1.325$ respectively. The fifth and sixth ranked skills were music composition $(M=4.41, S D=$ $1.248)$ and music improvisation $(M=4.74, S D=1.163)$.

\section{Comfort Levels}

Survey 1 revealed that many students (61\%) did not feel anxiety about the research process (see figure 2). Forty-four percent strongly or somewhat agreed that they were "very confident" in their ability to conduct high-quality music research. When asked about specific research and writing skills, which included synthesizing information,

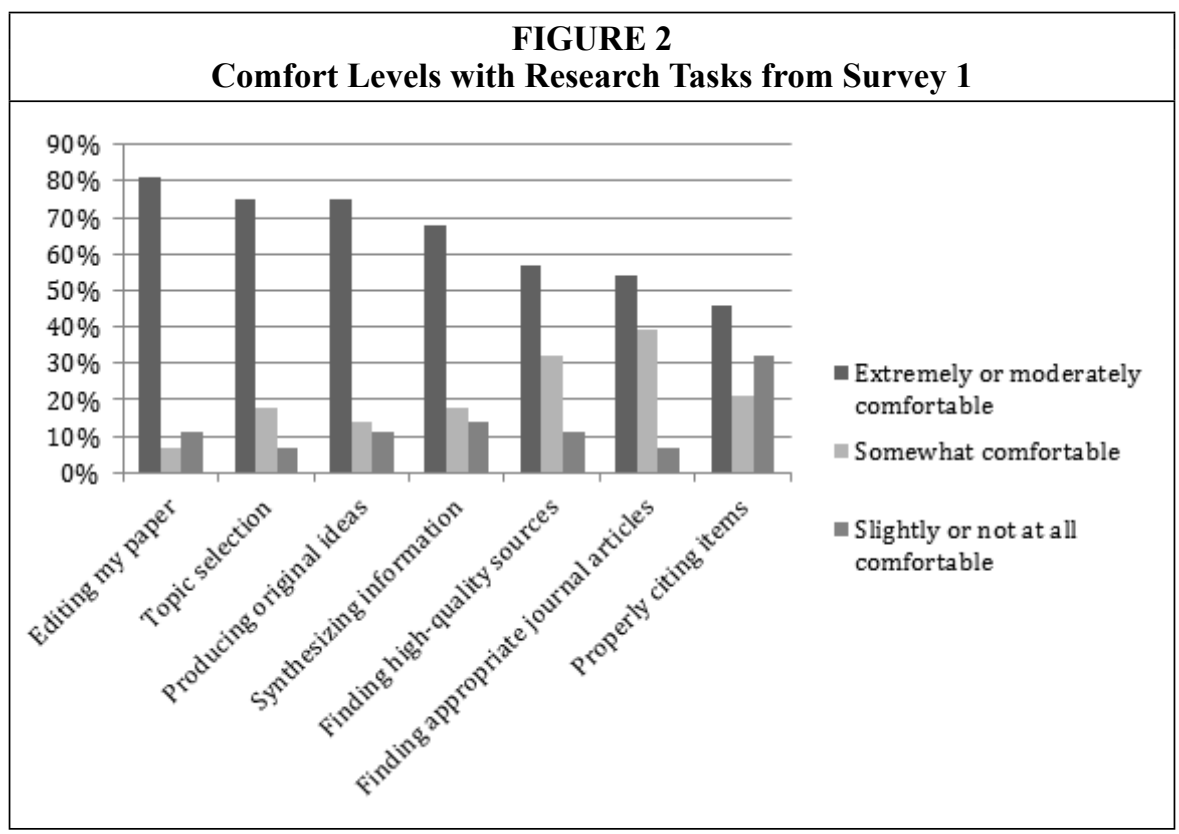


producing original ideas, selecting topics, avoiding plagiarism, and editing, students were self-assured. However, one concern seemed to be the ability to correctly cite resources, with 32 percent of respondents being "slightly" or "not at all" comfortable with this aspect of the process. Other areas of relatively low confidence included locating high-quality sources and appropriate journal articles.

Although students expressed confidence in selecting a paper topic, almost half (48\%) noted difficulties with narrowing its scope. "Too much information syndrome" was apparently a worry for some students, given that 46 percent strongly or somewhat agreed that "I have problems with research because I am overwhelmed by all of the information out there."

\section{Starting the Research Process}

Questions in the two focus groups and the surveys inquired about students' typical steps at the beginning of a research project. Focus group participants described their initial work as "informal research," a process that involves becoming familiar with their topic in a casual manner using multiple sources. Informal research provides students with sufficient background for proceeding with formal research. A focus group participant stated

...I will typically start by doing ...informal research first and foremost informing myself so I know what to look for ...let's say my research paper is on Gil Evans the first thing that I'll do is I'll just Google Gil Evans and just kinda see what is out there, like look on his website that is set up in his name or look at the Gil Evans project, or even talk to some of my professors ...just to inform myself, not to write anything down, but just to get an idea of what information is out there and what I should start looking for and then from there, once I have an idea of what is out there I'll start doing more formal research ...but I think that starting informative is an important step that a lot of people sometimes miss because they are concerned about doing formal research first and I think it is really important to first and foremost inform yourself before you start writing something.

The above comment generated similar statements within the focus group. Another student claimed that "informal research is absolutely critical." He explained that he had learned on Wikipedia that the American premiere of Mahler's First Symphony was performed by the New York Philharmonic. This led him to find a book on the organization that contained information he "wasn't able to find anywhere else," and "wouldn't have thought to have even looked there if it weren't for the informal research stage." Another student's process commenced with a Google search that resulted in locating a website on Paul Hindemith that provided a large amount of biographical information.

Participants in both surveys selected their first, second, and third tasks when beginning a music research paper. Survey 1 asked students to identify their general steps for a music research paper, while survey 2 inquired about specific steps they had taken to complete their course's research paper (see figure 3). Both offered twelve options, including "don't know" and other "(fill in)." On survey 2, "use a search engine (e.g., Google, Bing, Yahoo!)" was the most frequent first step (38\%); however, it also ranked high as a second step (25\%). Online scholarly resources were selected by 17 percent as their first step and by 33 percent as their second step (it was the most common second step). Almost half (44\%) of those surveyed at the end of the semester who chose a search engine as their first step used an online scholarly source for their second step. Visiting the Performing Arts Library for physical items was another common second and third step ( $21 \%$ and $17 \%$ respectively); it was followed closely by textbook, class 


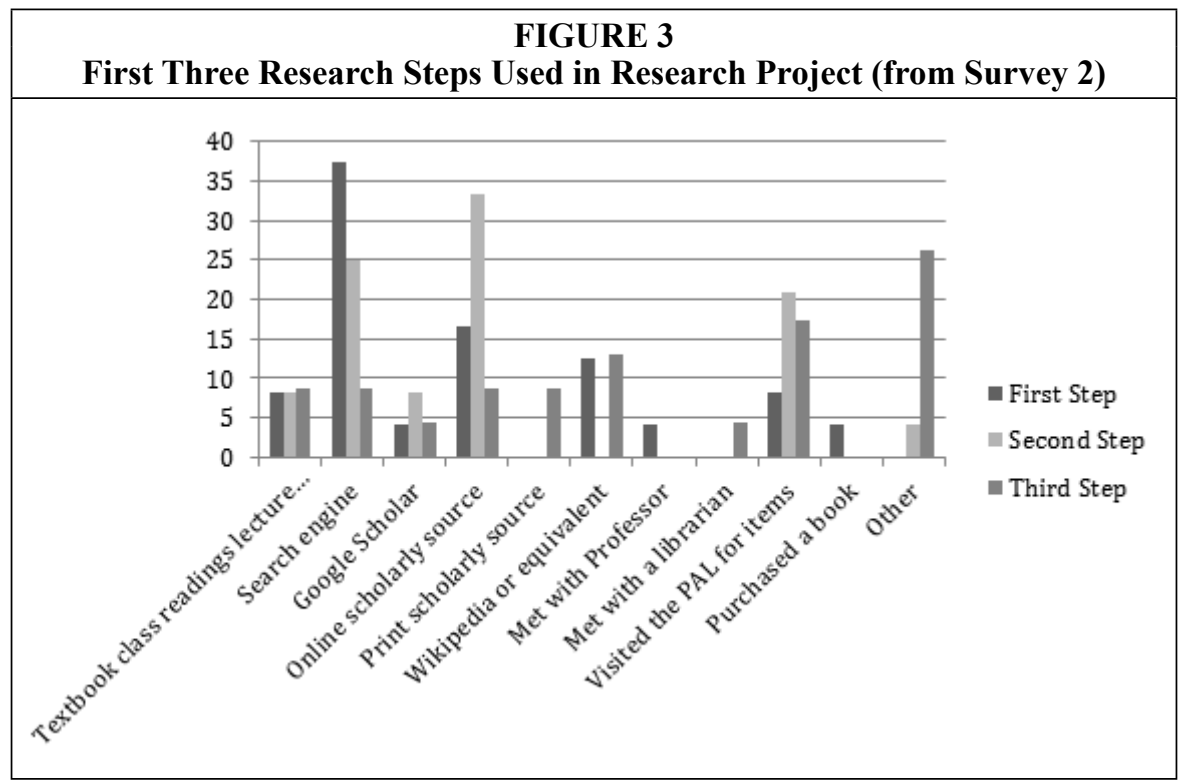

readings, and/or lecture notes (18\%). Third steps were the most varied: 26 percent selected "other" (this frequently included speaking with applied instructors).

A belief that Google is a valuable tool for music research was also evidenced by responses to agree/disagree statements. Sixty-nine percent of students strongly or somewhat agreed that "Google is an excellent starting point for music research." Only 8 percent disagreed, and 23 percent of students were neutral. Almost half (48\%) somewhat or strongly agreed with the statement "Google provides plenty of credible, citable information for music research papers." One-fifth (20\%) disagreed. Nearly onethird of students (32\%) neither agreed nor disagreed.

Focus group participants described using Google for a number of research tasks, such as defining terms, obtaining background on a composer, and language translations. Google, and to a lesser extent Google Scholar, was also an important tool in students' informal research as described above.

Because Wikipedia was of special interest to the authors, one survey question rated the frequency with which students start research assignments with this free online encyclopedia. Only 11 percent of respondents claimed to use it "almost every time," while 14 percent indicated they did sometimes or occasionally. Most reported never (39\%) or almost never (32\%) commencing with Wikipedia. Students in both focus groups indicated using it for finding biographical data on a composer. Several referenced the citations at the bottom of article pages and noted that those sometimes served as a list of resources they would later consult. Some students also stated that they accessed Wikipedia pages of composers for personal use but would either not use them for academic purposes or would at least not cite the source. Some also claimed to use Wikipedia for musical terms and for translating song texts from foreign languages.

\section{Resources}

Most students indicated a high level of comfort with, and frequent use of, the KentLINK local library catalog and the consortial Ohio catalog (OhioLINK). All survey participants had heard of both catalogs. Only 8 percent had not used them. Worldcat had never been used by 63 percent, although two-thirds of those who had were comfortable with it. 
A majority of survey respondents reported that they had accessed both print and electronic scholarly journals prior to the current semester (63\% and $67 \%$ respectively). Further, they signaled comfort with these formats. Obtaining articles and other materials through InterLibrary Loan was not a common practice, however, as 63 percent had not used this service. Forty-two percent claimed not to have heard of InterLibrary Loan, although it had been covered in a library instruction class session. Similarly, Garland Music Online and print encyclopedias were not used at rates of 67 percent and 70 percent respectively. Forty-six percent of survey 2 respondents had never worked with Oxford Music Online, an important library music reference source that was addressed during a library instruction session.

Free Internet resources were most commonly used for academic music projects among survey 2 participants. All of these students knew about/used Google and Wikipedia. At least half had visited blogs, Britannica.com, and Google Scholar before the semester and were comfortable with them (58\%, 54\%, and 50\% respectively).

Students were split on the statement "I have problems evaluating the credibility of a given source," with 43 percent agreeing, 43 percent disagreeing, and 14 percent neither agreeing nor disagreeing. Over half (54\%) of survey 1 participants claimed to "only use authoritative sources for research assignments" almost every time or every time. The remainder (46\%) said that they did so occasionally/sometimes. Most students (70\%) claimed to "find plenty of credible sources when completing a research assignment" almost every time or every time, and 30 percent reported doing so occasionally/sometimes.

The overwhelming majority of focus group participants believed that library resources were more authoritative than general Internet resources. Focus group quotations show students discussing their preferences for library resources:

I like library resources better because they tend to be more academic based instead of, like I said, research on Google can be somebody's opinion or a whole article about this composer's life but it could just be someone's take on it instead of what actually happened, and you don't always know so it is nice to have everything on the library website and the books that we use are academic based so that is nice to know that they are probably going to be reliable...

...trust factor, you don't have to worry about if a library resource is going to be credible or not where with the other resources online it might be that you have to approach everything with a little bit of skepticism before you take it at its value.

Other comments include "I think that the library resources are more trustworthy..." and "...it is just something that I feel that I can trust more-the university approved of it." One suggested that either library or nonlibrary resources were acceptable, but that she chose to "[err] on the side of the library."

Fifty-seven percent of survey 1 participants agreed or strongly agreed that "all of the relevant information (for music research) that I need is online." While just over one-third (36\%) said that they never or almost never "use whatever I can find online that looks good for research assignments," 21 percent apparently did so every or almost every time. Forty-three percent claimed to sometimes/occasionally use whatever they find online that "looks good."

At the same time, almost half of the surveyed students indicated that they had experienced problems with locating the right physical and electronic resources. Fortyeight percent encountered issues in finding appropriate physical items, and 44 percent encountered problems locating the acceptable electronic library resources. 
When queried about physical vs. virtual formats, about one-third of survey 1 participants somewhat or strongly agreed with the statement "I prefer to use print resources." One-third neither agreed nor disagreed. The remaining third somewhat or strongly disagreed. Focus group students were also split over format preferences; a number of them indicated a liking for both physical and electronic items. Those who preferred electronic formats cited easy access, convenience, and the ability to quickly find relevant content using the "find" function. One participant, a commuter student, felt that electronic was better due to ease of access to information. Another described waiting for a book as an uncertain process (that is to say, not knowing when or if it will arrive) compared with the immediacy of using electronic sources. Time and convenience typically factored into which format students ultimately chose; one respondent said that "if I am going to be here all day, then I want to get physical copies, but if I am not here, then electronic is probably going to be the only thing that I can do. So it is not really just about convenience but what can you do."

Students who most valued physical items mentioned ease of organization and the ability to use post-it notes or write on/highlight photocopies and spread everything out. Students from both focus groups described printing electronic journal articles so they could hold them in their hands. Several claimed to carry print music and/or language dictionaries in their school bags.

\section{Other Obstacles and Getting Help}

Finding the time to conduct research appeared problematic for many students. Eightyfive percent somewhat or strongly agreed that "time pressures strongly influence how I approach research activities." Only 11 percent somewhat disagreed with this statement, and no students strongly disagreed. Focus group participants claimed that their largest research obstacles were finding good resources, writing about a specific piece of music, generating a thesis statement, and establishing credibility of various authors.

Survey 2 results indicated that the most common sources for in-person assistance during the semester studied were: 1) a classmate or colleague; 2) the professor; and 3) a librarian. Fifty-eight percent of survey participants reported getting help from a classmate or colleague, compared to 38 percent from their instructor or 29 percent from a librarian. Similarly, one focus group member stated, "I have learned a lot from other students and different professors, and having them help guide my research." Another said:

When I am doing research on anything, and I am having trouble finding information or trying to find correct information or see what I can put into my paper, depending on what the topic is ...I use people in my class rather than going to the professor. If I have a ... question about what needs to be done, then I'll go straight to the professor. But if it is about information, like if we were in the same class, I'd sit there and ask ...how are you going about finding your information? Or if it is on the same topic, do we get together with someone? And you start here, and then we can compare and see what we have? I like [working with] friends, and going about it that way rather than with teachers because I am very teacher friendly, but I get uncomfortable around adults even though I am one, but like, teacher figures, unless it is my voice teacher, I ...don't want to say something wrong and look stupid. I don't care if I look stupid around my friends.

Results from survey 1 indicated that 54 percent of students "never" or "almost never" sought out a librarian in their previous research experiences. Twenty-one percent met with their instructor with this frequency. Correspondingly, only 11 percent 
conferred with a librarian "almost every time" or "every time"; 29 percent met with their instructor with this frequency. According to survey 2, 71 percent did not consult with a librarian at all, although 83 percent met with their professor. One focus group participant stated, "I go to the professor, which usually is not an issue, but I'll just start with the professor, I know that people help in the library, but it seems weird to ask for help ...the professor is always fine." Only one student (of $24,4 \%$ ) mentioned using other sources of help, suggesting that most students don't seek assistance outside their academic network.

Survey 2 indicated that at least half of the students preferred to work on their own or with friends rather than seeking help from instructors or librarians. Fifty percent either "somewhat agreed" (32\%) or "strongly agreed" (18\%) with the statement "I prefer to figure out how to conduct research on my own or with help from friends." Twentynine percent "neither agreed or disagreed," while only 21 percent either "somewhat disagreed" (14\%) or "strongly disagreed" (7\%). These students rarely took advantage of various campus services, such as library tutorials or the Writing Center. In survey 2,13 percent $(n=3$ of 24$)$ reported referring to a library tutorial, while only $4 \%(n=1$ of 24) accessed the Writing Center. The exception to this was an online Chicago style guide, used by 83 percent of students.

Most students from survey 1 reported that either "getting the assignment finished" $(30 \%)$ or "learning something new" $(30 \%)$ was the most important goal in writing their music history paper. Another 15 percent of students chose "being creative with the assignment." When asked again toward the end of the semester in survey 2, "getting the assignment finished" and "learning something new" responses were down, and there were no "being creative..." responses. As the assignment due date drew near, 38 percent of students were worried about their grade, but interestingly, 8 percent chose "improving my research skills" as the most important (which was not selected by any respondents in survey 1).

\section{Observed Student Abilities}

We have thus far looked at students' perceptions of their own research and writing processes. Finding quality resources - and, to an even greater extent, the ability to cite them properly - were the skills in which students had the least amount of confidence (see figure 2). The following section examines the students' actual competencies and compares them with their perceptions, specifically with regard to finding, evaluating, and properly citing resources. Two measures of student output were used in the following analysis: the Research Task Assessment (RTA) and the music history research papers.

\section{Finding and Evaluating Resources}

The RTA consisted of five tasks: 1 ) cite a given book in Chicago/Turabian bibliographic style; 2) cite a given chapter in an edited volume; 3) find, cite, and use resources to answer an essay question about Renaissance music; 4) locate a specific journal article and type the final eight words; and 5) find an academic article about Beethoven's Fourth Piano Concerto.

The instructor rated the quality of resources for tasks 3 and 5 by using a scale from 0 (unacceptable) to 5 (excellent). Quality of resources was slightly better in task 3 than in task $5(M=3.75, S D=1.71$ versus $M=3.5, S D=1.98)$. Furthermore, nearly half of students ( 5 of 12) outright failed to successfully identify an academic article for task 5 . Instead, they listed scores, reviews of recordings-or in one case, an orchestra's website.

As noted earlier, focus group students expressed preferences for "library resources." However, RTA task 4 demonstrated that many did not use the library's website for 
connecting to licensed databases. Instead, while all students located the given article, 58 percent of them Googled the citation, and from Google connected to JSTOR.

Difficulty with finding and using quality resources was evident in the music history research papers. The bibliographies for both the rough and final drafts were consistent with the results of the RTA, in which students conducted general online searches rather than used library databases. The papers also confirmed that students struggled with locating quality resources for music research. Although focus group participants said that they preferred library sources, free nonlibrary-affiliated websites remained the most frequently used resources, making up 38 percent of those cited in rough drafts and a staggering 46 percent of all sources used in the final papers.

The authors categorized the cited websites from students' papers into four groups. The most common, with 34 citations, were music websites for nonspecialists (including classical.net, allmusic.com, theopera101.com, and blogs); these made up 47 percent of all websites used. The second grouping was general reference sites (also for nonspecialists, such as wikipedia.org, britannica.com, encyclopedia.com, A\&E's bio.com, and merriam-webster.com), which had 20 citations (27\% of all used). The third type, professional performers' sites and periodicals (including metopera.org, laphil.com, washingtonpost.com, nytimes.com), appeared 13 times (18\%). University textbooks and companion sites (including library.yale.edu, nyu.edu/classes, and oxfordwesternmusic.com) were used six times (8\%). Additionally, Youtube.com, the most common source for audio, was cited by nearly half of students (13 of 28) in their final papers. Students also used two library-subscribed streaming audio databases: three students cited Naxos, and one cited Classical Music Library by Alexander Street Press. However, some did not include any audio resources in their bibliographies; therefore, it may be that even more students used these websites to listen to their chosen piece(s). No one cited any CDs, cassettes, or LPs.

Print books comprised one-quarter of total resources for both rough drafts and final papers. The percentage of journal articles actually declined slightly between the rough drafts and final papers, from 28 percent $\left(24 \%\right.$ online and $4 \%$ with no URL $\left.{ }^{22}\right)$ to 20 percent ( $15 \%$ online and $5 \%$ with no URL). Online dissertations and Oxford Music Online represented a relatively small proportion of sources, although both increased slightly from rough drafts to final versions ( $1 \%$ to $2 \%$ for dissertations, and $4 \%$ to $6 \%$ for Oxford).

Students were required to reference at least one academic journal article in their music research paper; in total, 31 journal articles were used in 28 final papers. However, these were not evenly distributed. Thirty-nine percent of students used no journal articles at all, and 39 percent used just one. Of the remaining 22 percent, 11 percent used three articles each, while the other 11 percent (three students) used two, four, and five articles respectively.

\section{Properly Citing Sources}

The RTA required students to cite resources in four different tasks. The instructor rated the citations on a scale from 0 (unacceptable) to 5 (correct) and considered both the quantity and the quality of errors (for example: content errors were considered larger mistakes than, say, missing italics). Students were also asked how satisfied they were with their citations for tasks 1,2, and 5. Despite dismal results, students seemed content with their work (see figure 4).

Task 1 required students to cite a single-authored book; unfortunately, only three of twelve were correct. Citing a chapter in an edited volume (task 2) fared worse, with only one of twelve completed accurately. In task 3, students had to find resources based on a given topic. One student chose a single-authored book and cited it without er- 


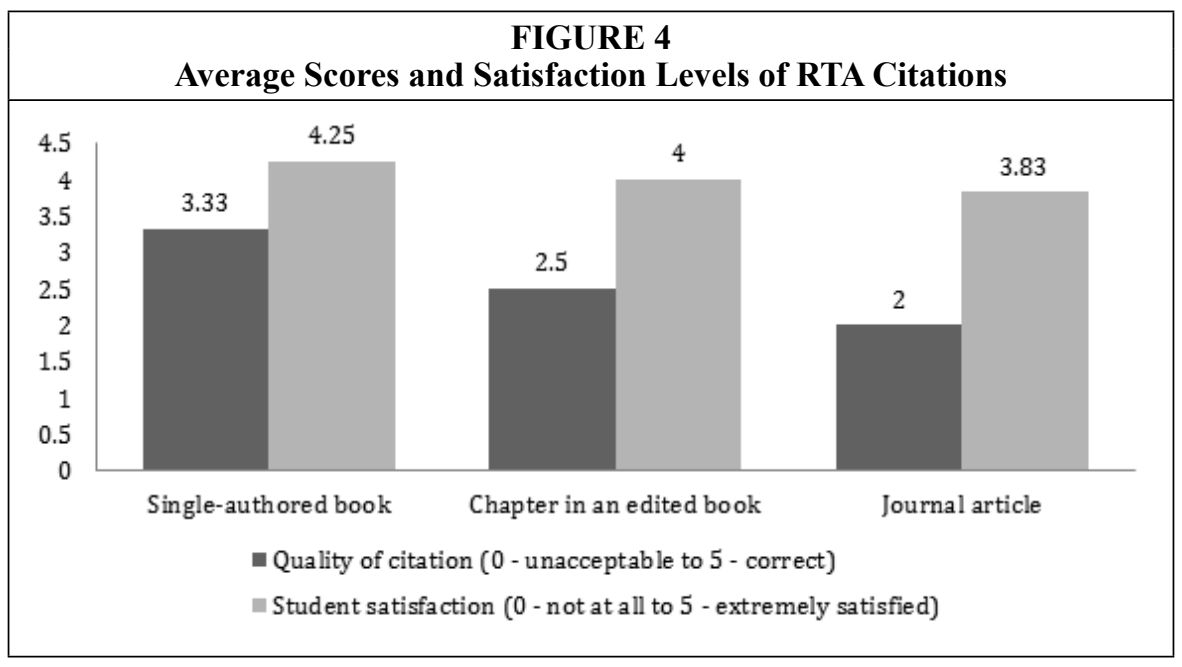

rors. The others chose online articles from journals, Wikipedia, Oxford Music Online, or periodicals. Citation quality was slightly better in task 3 , with a mean rating of 3.5 $(S D=1.62)$.

Task 5 required students to find an academic article; these were the poorest citations of the RTA $(M=2, S D=1.41)$. Not one was cited correctly. While it is true that many were not academic articles in the first place (as discussed above), if we remove all resources that were not articles, the mean score was still only $2.43(S D=1.43)$. These results might specifically indicate unfamiliarity with journal articles.

Follow-up questionnaires and verbal reports shed light on why students answered as they did on the RTA. For example, in task 1, two of twelve students added Ludwig van Beethoven, twice, as coauthor(s) to Charles Rosen for his book The Classical Style: Haydn, Mozart, Beethoven, producing a citation that looked like this:

Rosen, Charles, Ludwig Van Beethoven, and Ludwig Van Beethoven. The Classical Style: Haydn, Mozart, Beethoven. Expanded Edition. New York: W.W. Norton, 1997.

The debrief revealed that both students used online citation generators (citationmachine.net and citethisforme.com).

The final research papers' bibliographies corroborated the RTA results. The same scale (0-5) was used to grade each citation, and each student's mean score was recorded. The class averaged 3.41. Only 2 of 28 papers (7\%) had perfect bibliographies. Another $7(25 \%)$ cited more or less correctly, but had spacing and/or minor punctuation issues, with mean scores between 4 and 4.6. Nearly half of the final papers (13, or $46 \%$ ) contained citations that fell between 3 and 3.82; these students typically produced a couple of correct citations, but most lacked important content or consistently made formatting mistakes. Six papers $(21 \%)$ scored between 0 and 2.75 . The citations were missing major components, had additional unnecessary information, and were generally formatted incorrectly.

\section{Conclusion}

When asked about their anxieties at the start of the semester, students in this study seemed fairly undaunted by the prospect of writing a music research paper. Their concerns with tasks such as synthesizing information, producing original ideas, selecting topics, and avoiding plagiarism were minimal; this was consistent with the quality 
of these aspects in their final papers. Students did express some reservations about finding quality resources and being able to cite them properly.

However, such reservations appeared only when students were asked in the abstract: in practice, their confidence outweighed their abilities. For example, consider the RTA, in which students' comfort and satisfaction with their output did not at all positively correlate with the quality of their work. Furthermore, the relatively meager number of quality resources used in final papers, as well as the fact that only 7 percent of students produced correctly cited bibliographies, also suggests a disconnect between students' perceived competence versus their actual performance. A related contradiction was also suggested by students in focus groups prioritizing library resources but failing to use library databases in the RTA or their final papers.

It is important to note that these students received detailed instruction from their professor throughout the semester, including suggested resources and citation guides. The instructor provided handouts containing sample citations, advice, and directions for navigating the library databases. She also frequently e-mailed the students and posted instructions, ideas, and web links to the course website. Approximately two weeks of course time was spent on in-class activities aimed at better research, writing, and citation skills. These sessions included, but were not limited to, time spent in the library's computer lab citing and discussing sources in groups. Additionally, the Performing Arts librarian provided a fifty-minute lecture/workshop on effective methods for finding and evaluating resources. Yet in spite of receiving this explicit instruction, when it came time to write their papers, most music majors struggled (particularly with finding and citing academic resources).

We concluded that most junior and senior music majors at our institution have limited experience with writing and research and that most prioritize performance and teaching skills. It may be that the relatively minor importance that students placed on research and writing skills influenced them to not engage in what they had been told regarding good practices throughout the semester. Furthermore, resistance to seeking help-other than from fellow students-was likely a contributing factor to the poor quality of their work. During previous semesters, the instructor conducted individual conferences; however, as class sizes continued to increase, this was no longer possible.

Other notable conclusions showed that an informal stage of information gathering before beginning "official" research is common among students, and search engines and physical materials played important roles in this process. Importantly, students surveyed for this study claim to use "online scholarly sources" more than any other type of resource during the first, second, and third steps of their research process (see figure 3). Yet, given the scarcity of academic resources in their finished products, it leaves one to wonder: what are their criteria for assessing the academic quality of a resource?

While this study revealed much about students' perceptions of research and writing, it contained limitations. Because the sample size was approximately 40 students from one institution in one semester, these data may not be representative of music majors from other classes or from other institutions. Nevertheless, it suggests that instructors and librarians may want to focus more attention on information literacy among music majors, preferably before their third and fourth years: one semester of research instruction does not appear to be sufficient, especially when couched in a course with a large volume of content. Current curricular requirements prior to Music History II, which include two English composition courses, likewise do not seem to be enough for most of our students to succeed in researching and writing about music.

Another limitation was the failure to identify each survey participant with an identifier; hence we were limited as to how we could compare responses from survey 1 to survey 2 . That said, the surveys as a whole provided invaluable information regard- 
ing this group of students' perceptions of their own research abilities (which we then compared with their submitted work). Given the meager number of students who actually found and used quality resources in their papers, and the equally disappointing number of correct citations in the final papers, we were able to confidently argue that overall, inadequate information literacy is an issue that students themselves may be unaware of, and it certainly warrants attention.

We found that this study provided valuable insights into the actual competencies of music juniors and seniors and that their mindset and processes mirror that of students from other disciplines. These included: 1) a preference for help from friends over instructors and librarians; 2) time constraints influencing their research process; 3) use of search engines as a starting point; 4) being overwhelmed by the number of resources, as well as problems determining credibility; 5) anxiety with the research process; and 6) overconfidence in their abilities to find and cite information.

The authors will share these results with School of Music faculty with the hope that they will consider integrating additional information literacy instruction in their own courses. We also hope that such investigations are mimicked by colleagues in other disciplines and that new effective strategies are shared. These might allow for a more thorough understanding of actual student abilities, perceptions, and processes. As many graduates will find themselves in occupations outside their field of study, it is crucial to instill information literacy and critical thinking skills into all curricula. 


\section{APPENDIX A. Focus Group Questions}

How do you approach research tasks for coursework? Where do you go for:

1. Terms (definition)

2. Background on a composer

3. Information on a piece of music (when, where composed, how it fits in to the composer's output, and so on)

4. Translation

What resources do you choose to start your music research?

What is your comfort level with academic libraries and their entire scope of resources?

In general, do you prefer physical or electronic resources for music research?

Do you have a preference for library sources or nonlibrary sources?

Is there a differing approach for your research in music versus nonmusic research?

What are the biggest challenges/barriers for conducting music research?

\section{APPENDIX B. Research Task Assessments}

\section{Kent State University Music Research “Scavenger Hunt”-Spring 2016}

-Pretest \& Instructions-

Please indicate your comfort level with each of the following research skills:

\begin{tabular}{|l|c|c|c|c|c|}
\hline Research Skill & $\begin{array}{c}\text { Extremely } \\
\text { Comfortable }\end{array}$ & $\begin{array}{c}\text { Moderately } \\
\text { Comfortable }\end{array}$ & $\begin{array}{c}\text { Somewhat } \\
\text { Comfortable }\end{array}$ & $\begin{array}{c}\text { Slightly } \\
\text { Comfortable }\end{array}$ & $\begin{array}{c}\text { Not at All } \\
\text { Comfortable }\end{array}$ \\
\hline $\begin{array}{l}\text { Finding a } \\
\text { specific journal } \\
\text { article with a } \\
\text { citation }\end{array}$ & $\square$ & $\square$ & $\square$ & $\square$ & $\square$ \\
\hline $\begin{array}{l}\text { Locating } \\
\text { appropriate } \\
\text { high-quality } \\
\text { sources for } \\
\text { open-ended } \\
\text { scholarly } \\
\text { questions }\end{array}$ & $\square$ & $\square$ & $\square$ & $\square$ & $\square$ \\
\hline $\begin{array}{l}\text { Properly citing } \\
\text { books }\end{array}$ & $\square$ & $\square$ & $\square$ & $\square$ & $\square$ \\
\hline $\begin{array}{l}\text { Properly citing } \\
\text { book chapters }\end{array}$ & $\square$ & $\square$ & $\square$ & $\square$ & $\square$ \\
\hline $\begin{array}{l}\text { Properly citing } \\
\text { journal articles }\end{array}$ & $\square$ & $\square$ & $\square$ & $\square$ & $\square$ \\
\hline
\end{tabular}

Please rate the frequency with which you do each research skill: 


\begin{tabular}{|l|c|c|c|c|c|c|}
\hline \multicolumn{1}{|c|}{ Statement } & $\begin{array}{c}\text { Never } \\
\text { have } \\
\text { done } \\
\text { this }\end{array}$ & $\begin{array}{c}\text { I've done } \\
\text { this a } \\
\text { couple } \\
\text { of times } \\
\text { before }\end{array}$ & $\begin{array}{c}\text { A couple } \\
\text { of times a } \\
\text { semester }\end{array}$ & $\begin{array}{c}\text { A couple } \\
\text { of times } \\
\text { a month } \\
\text { during } \\
\text { school }\end{array}$ & $\begin{array}{c}\text { A } \\
\text { couple } \\
\text { of } \\
\text { times } \\
\text { a week }\end{array}$ & $\begin{array}{c}\text { Don't } \\
\text { know }\end{array}$ \\
\hline $\begin{array}{l}\text { Locate a specific journal } \\
\text { article from a citation }\end{array}$ & $\square$ & $\square$ & $\square$ & $\square$ & $\square$ & $\square$ \\
\hline $\begin{array}{l}\text { Locate appropriate } \\
\text { high-quality sources for } \\
\text { coursework }\end{array}$ & $\square$ & $\square$ & $\square$ & $\square$ & $\square$ & $\square$ \\
\hline $\begin{array}{l}\text { Cite a book using Chicago/ } \\
\text { Turabian or APA }\end{array}$ & $\square$ & $\square$ & $\square$ & $\square$ & $\square$ & $\square$ \\
\hline $\begin{array}{l}\text { Cite a journal article using } \\
\text { Chicago/Turabian or APA }\end{array}$ & $\square$ & $\square$ & $\square$ & $\square$ & $\square$ & $\square$ \\
\hline
\end{tabular}

\section{Demographic Information}

What is your class standing? $\square$ Freshman $\square$ Sophomore $\square$ Junior $\square$ Senior

What is your gender?

What is your age? $\square$ 18-21 $\square 22-25 \square 26-30 \square 31+$

Music Major: List area of concentration/study (music education, performance, and so on)

What is your current GPA?

\section{Kent State University Music Research “Scavenger Hunt”-Spring 2016}

\section{-Post Assessment Debrief -}

Student code:

Cite the book using Chicago/Turabian style (bibliographic style, not notes) that you are given by the proctor.

\begin{tabular}{|l|c|c|c|c|c|}
\hline Ease/Difficulty & $\begin{array}{c}1 \\
\text { Very Easy }\end{array}$ & $\begin{array}{c}2 \\
\text { Easy }\end{array}$ & $\begin{array}{c}3 \\
\text { Neutral }\end{array}$ & $\begin{array}{c}4 \\
\text { Difficult }\end{array}$ & $\begin{array}{c}5 \\
\text { Very Difficult }\end{array}$ \\
\hline \hline $\begin{array}{l}\text { Satisfaction w/ } \\
\text { Outcome }\end{array}$ & $\begin{array}{c}1 \\
\text { Not Satisfied } \\
\text { at All }\end{array}$ & $\begin{array}{c}2 \\
\text { Slightly } \\
\text { Satisfied }\end{array}$ & $\begin{array}{c}3 \\
\text { Moderately } \\
\text { Satisfied }\end{array}$ & $\begin{array}{c}\text { Very } \\
\text { Satisfied }\end{array}$ & $\begin{array}{c}\text { Extremely } \\
\text { Satisfied }\end{array}$ \\
\hline
\end{tabular}

What source (s) did you use/consult in providing your response?

Provide a reference citation (not notes format) in the Chicago/Turabian style for the book chapter noted in the book provided by the proctor. Format the citation just as you would for a paper or class assignment.

\begin{tabular}{|c|c|c|c|c|c|}
\hline Ease/Difficulty & 1 & 2 & 3 & 4 & 5 \\
& Very Easy & Easy & Neutral & Difficult & Very Difficult \\
\hline
\end{tabular}


Exploring Research Mindset and Information-Seeking Behaviors 515

\begin{tabular}{|l|c|c|c|c|c|}
\hline $\begin{array}{l}\text { Satisfaction w/ } \\
\text { Outcome }\end{array}$ & $\begin{array}{c}1 \\
\text { Not Satisfied } \\
\text { at All }\end{array}$ & $\begin{array}{c}2 \\
\text { Slightly } \\
\text { Satisfied }\end{array}$ & $\begin{array}{c}3 \\
\text { Moderately } \\
\text { Satisfied }\end{array}$ & $\begin{array}{c}4 \\
\text { Very } \\
\text { Satisfied }\end{array}$ & $\begin{array}{c}5 \\
\text { Extremely } \\
\text { Satisfied }\end{array}$ \\
\hline
\end{tabular}

What source (s) did you use/consult in providing your response?

Answer the following question as you would for a class assignment using whatever resource (s) you would normally use under such circumstances. Cite your resource(s) using bibliographic format for Chicago/Turabian style.

Question: What was L'homme armé? How is it representative of broader compositional tendencies in the Renaissance?

\begin{tabular}{|c|c|c|c|c|c|}
\hline Ease/Difficulty & $\begin{array}{c}1 \\
\text { Very Easy }\end{array}$ & $\begin{array}{c}2 \\
\text { Easy }\end{array}$ & $\begin{array}{c}3 \\
\text { Neutral }\end{array}$ & $\begin{array}{c}4 \\
\text { Difficult }\end{array}$ & $\begin{array}{c}5 \\
\text { Very Difficult }\end{array}$ \\
\hline $\begin{array}{l}\text { Satisfaction w/ } \\
\text { Outcome }\end{array}$ & $\begin{array}{c}1 \\
\text { Not Satisfied } \\
\text { at All }\end{array}$ & $\begin{array}{c}2 \\
\text { Slightly } \\
\text { Satisfied }\end{array}$ & $\begin{array}{c}3 \\
\text { Moderately } \\
\text { Satisfied }\end{array}$ & $\begin{array}{c}4 \\
\text { Very } \\
\text { Satisfied }\end{array}$ & $\begin{array}{c}5 \\
\text { Extremely } \\
\text { Satisfied }\end{array}$ \\
\hline
\end{tabular}

What source (s) did you use/consult in providing your response?

Write out the last eight words from the article "Mahler in a New Key: Genre and the 'Resurrection' Finale" by Thomas Bauman from the Journal of Musicology, vol. 23, no. 3 (Summer 2006): 468-85. (Note: final eight words of the article, not the abstract which follows the article).

\begin{tabular}{|c|c|c|c|c|c|}
\hline Ease/Difficulty & $\begin{array}{c}1 \\
\text { Very Easy }\end{array}$ & $\begin{array}{c}2 \\
\text { Easy }\end{array}$ & $\begin{array}{c}3 \\
\text { Neutral }\end{array}$ & $\begin{array}{c}4 \\
\text { Difficult }\end{array}$ & $\begin{array}{c}5 \\
\text { Very Difficult } \\
\end{array}$ \\
\hline $\begin{array}{l}\text { Satisfaction w/ } \\
\text { Outcome }\end{array}$ & $\begin{array}{c}1 \\
\text { Not Satisfied } \\
\text { at All }\end{array}$ & $\begin{array}{c}2 \\
\text { Slightly } \\
\text { Satisfied }\end{array}$ & $\begin{array}{c}3 \\
\text { Moderately } \\
\text { Satisfied }\end{array}$ & $\begin{array}{c}4 \\
\text { Very } \\
\text { Satisfied }\end{array}$ & $\begin{array}{c}5 \\
\text { Extremely } \\
\text { Satisfied }\end{array}$ \\
\hline
\end{tabular}

What source (s) did you use/consult in providing your response?

Find an academic journal article in the English language that focuses on Beethoven's fourth Piano Concerto in G major, Op. 58. Provide the citation to the article using Chicago/Turabian style with bibliographic format (not notes format):

\begin{tabular}{|c|c|c|c|c|c|}
\hline Ease/Difficulty & $\begin{array}{c}1 \\
\text { Very Easy }\end{array}$ & $\begin{array}{c}2 \\
\text { Easy }\end{array}$ & $\begin{array}{c}3 \\
\text { Neutral }\end{array}$ & $\begin{array}{c}4 \\
\text { Difficult }\end{array}$ & $\begin{array}{c}5 \\
\text { Very Difficult } \\
\end{array}$ \\
\hline $\begin{array}{l}\text { Satisfaction w/ } \\
\text { Outcome }\end{array}$ & $\begin{array}{c}1 \\
\text { Not Satisfied } \\
\text { at All }\end{array}$ & $\begin{array}{c}2 \\
\text { Slightly } \\
\text { Satisfied }\end{array}$ & $\begin{array}{c}3 \\
\text { Moderately } \\
\text { Satisfied }\end{array}$ & $\begin{array}{c}4 \\
\text { Very } \\
\text { Satisfied }\end{array}$ & $\begin{array}{c}5 \\
\text { Extremely } \\
\text { Satisfied }\end{array}$ \\
\hline
\end{tabular}

What source (s) did you use/consult in providing your response? 


\section{Notes}

1. There is also a Bachelor of Science in music technology at one of Kent State's regional campuses. Majors are required to take Music History I at the Kent campus but not the writingintensive Music History II. No music technology students participated in the current study.

2. Alison J. Head, "Information Literacy from the Trenches: How Do Humanities and Social Science Majors Conduct Academic Research?" College and Research Libraries 69, no. 5 (Sept. 2008): $427-45$.

3. Michelle D'Couto and Serena H. Rosenhan, "How Students Research: Implications for the Library and Faculty," Journal of Library Administration 55 (2015): 562-76.

4. Alison J. Head, "Learning the Ropes: How Freshmen Conduct Course Research Once They Enter College," Project Information Literacy Research Report: The Passage Studies (Dec. 5, 2013), available online at https://papers.ssrn.com/sol3/papers.cfm?abstract_id=2364080 [accessed 26 October 2016].

5. Eleonora Dubicki, "Writing a Research Paper: Students Explain Their Process," Reference Services Review 43, no. 4 (2015): 673-88.

6. Diane Mizrachi, “Undergraduates' Academic Information and Library Behaviors: Preliminary Results," Reference Services Review 38, no. 4 (2010): 571-80.

7. Mónica Colón-Aguirre and Rachel A. Fleming-May, "'You Just Type in What You Are Looking For': Undergraduates' Use of Library Resources vs. Wikipedia," Journal of Academic Librarianship 38, no. 6 (2012): 391-99.

8. Andrew D. Asher and Lynda M. Duke, "Searching for Answers: Student Research Behavior at Illinois Wesleyan University," in College Libraries and Student Culture: What We Now Know, eds. Lynda M. Duke and Andrew D. Asher (Chicago, Ill.: American Library Association, 2012), 84.

9. Susan Miller and Nancy Murillo, "Why Don't Students Ask Librarians for Help? Undergraduate Help-Seeking Behavior in Three Academic Libraries," in College Libraries and Student Culture: What We Now Know, eds. Lynda M. Duke and Andrew D. Asher (Chicago, Ill.: American Library Association, 2012), 49-70.

10. Lily Todorinova, “Wikipedia and Undergraduate Research Trajectories," New Library World 116, no. 3/4 (2015): 201-12.

11. Beth Bloom and Marta Mestrovic Deyrup, “The SHU Research Logs: Student Online Search Behaviors Trans-scripted," Journal of Academic Librarianship 41 (2015): 599.

12. Melissa Gross and Don Latham, "Attaining Information Literacy: An Investigation of the Relationship between Skill Level, Self-Estimates of Skill, and Library Anxiety," Library \& Information Science Research 29 (2007): 332-53.

13. Valeria E. Molteni and Emily K. Chan, "Student Confidence/Overconfidence in the Research Process," Journal of Academic Librarianship 41 (2015): 5.

14. Ann Medaille, "Creativity and Craft: The Information-Seeking Behavior of Theatre Artists," Journal of Documentation 66, no. 3 (2010): 327-47.

15. Shannon Marie Robinson, "Artists as Scholars: The Research Behavior of Dance Faculty," College \& Research Libraries 77, no. 6 (2016): 779-94.

16. Francesca Marini, "Archivists, Librarians, and Theatre Research," Archivaria 63 (2007): 7-33.

17. Jennifer Mayer, "Serving the Needs of Performing Arts Students: A Case Study," portal: Libraries and the Academy 15, no. 3 (July 2015): 409-31.

18. Joe C. Clark, "Information-Seeking Behavior and Library Use by Distance Education Graduate Music Education Students," Music Reference Services Quarterly 17, no. 4 (2014): 207-25.

19. Kirstin Dougan, "Finding the Right Notes: An Observational Study of Score and Recording Seeking Behaviors of Music Students," Journal of Academic Librarianship 41 (2015): 61-67.

20. Joe C. Clark, "Format Preferences of Performing Arts Students," Journal of Academic Librarianship 39, no. 3 (May 2013): 297-307.

21. Kirstin Dougan, "Information Seeking Behaviors of Music Students," Reference Services Review 40, no. 4 (2012): 558-73.

22. It may be that students did use an electronic version of these articles but failed to list the link and access date. However, the researchers assumed that these articles were print versions because of their lack of this information. 